\title{
NOTES
}

\section{AUTHENTICATION OF DISPUTED WRITINGS BY COMPARISON: THE EXPERT WITNESS}

In many instances the authentication of writings offered in evidence at a trial may be a purely formal matter; in others, it may be the primary issue in litigation. The latter is especially true in forgery and many extortion prosecutions. Strongly contested issues of authentication also may grow out of settlements of large estates where the genuineness of signatures on wills are in dispute. Often deeds to land, which was originally cheap but has greatly increased in value, must be defended against claims of forgery; and a challenge of the genuineness of a signature on a note or a check is a common defense. ${ }^{1}$

The generally accepted rule is that any document or writing purporting to be of a certain authorship must be authenticated before it may be admitted in evidence. ${ }^{2}$ In the ordinary case, where there is no dispute as to genuineness, proof may not be necessary. A few documents are self authenticating, ${ }^{3}$ and the opponent may concede the document's authenticity through a judicial admission. ${ }^{4}$ Counsel generally admit the genuineness of proposed documents unless they have reason to doubt their authorship. ${ }^{5}$ Moreover, modern practice acts facilitate obtaining admissions. Under many statutes, there is a judicial admission when the issue is not raised by the pleadings or by affidavit denying the genuineness of a writing. ${ }^{6}$ The use of pre-trial may further encourage admissions, ${ }^{7}$ and provisions which under certain circumstances impose liability for the reasonable expenses of proving matters as to which admissions were requested deter frivolous denials of authenticity. ${ }^{8}$

If put to proof of execution, the proponent of the writing may establish its authenticity by any of the generally accepted modes of direct or circumstantial evidence. ${ }^{9}$ He may propose a witness who is in one way or another familiar with the handwriting of the alleged author who testifies that, in his opinion, the writing is in the same hand as other writings the

1. Osborn, Questioned Document Problems 24, 25 (1944).

2. 7 WigMORE, EVIDENCE $\$ 2130$ (3d ed. 1940).

3. MCCORMICK, EVIDENCE $\S 186$ (1954).

4. See 7 WIG MORE, op. cit. supra note $2, \S 2132$.

5. Interview with Henry Reath, Esq., Philadelphia, Pa., Dec. 12, 1955.

6. 9 WIGMORE, op. cit. supra note $2, \S 2596$.

7. See 1 Moore, Federal Practice 823-24 (1938); McCormick, Evidence $\$ 186$ (1954).

8. See FED. R. Crv. P. 37(c).

9. 7 WIGMORE, op. cit. supra note $2, \S 2020$. 
witness has seen. ${ }^{10}$ When there is a real dispute as to the genuineness or the authorship of a writing, however, the mode of proof most often employed ${ }^{11}$ is the submission of genuine specimens of the alleged author's handwriting to the trier of fact who may compare them with the writing on the disputed document. ${ }^{12}$ To aid the trier of fact in this determination, witnesses who are specially qualified in the science of handwriting are requested to give their opinion by comparing in court the disputed document with the genuine specimens of the alleged author's writing. ${ }^{13}$

Proof of authorship by comparison of handwriting styles has a history of strong judicial resistance. It was long established in English law by the seventeenth century, ${ }^{14}$ but in that period it was unfairly and vindictively used by the prosecutors employed by James II to bring about the death of certain popular and heroic figures. ${ }^{15}$ "Comparison of hands" thus became associated with tyranny and oppression and was rejected in England and in the American colonies largely on emotional grounds. ${ }^{16}$ The English corrected the situation by statute in 1854,17 and the American states followed this example in quick succession. ${ }^{18}$ Today, "comparison of hands" by the trier of fact and by expert witnesses is accepted in every American jurisdiction. ${ }^{19}$ However, the opinion of the expert witness still is held in low regard in many jurisdictions. ${ }^{20}$ In light of the advancements of the techniques of handwriting analysis, these attitudes would no longer seem to be justified. Modern attempts to codify rules of evidence, such as the Uniform Rules of Evidence, have not attempted to deal with the problem. ${ }^{21}$ This Note will examine the problems of authentication by comparison evidence.

\section{Who May Compare}

Comparison of handwriting styles may be performed by a non-expert, the trier of fact, or an expert. The trier of fact and the expert gain their

10. MCCORMICK, EvIDENCE $\$ 189$ (1954). For an illustration of how scanty this familiarity need be, see In re Diggins' Estate, 68 Vt. 198, 34 Atl. 696 (1896), where the witness was held to be qualified to give his opinion on genuineness even though he had seen the writing of the alleged author once, twenty years before.

11. Interview with Leon Webster Melcher, Esq., Examiner of Questioned Writing and Documents, Philadelphia, Pa., Dec. 19, 1955.

12. MCCORMICK, EVIDENCE $\$ \S 189,172$ (1954).

13. Id. $\S 172$.

14. 3 Chamberlayne, The Modern Law of Evidence, $\$ \$ 2214 c, 2273$ (1912).

15. 3 Id. $\$ 2214 \mathrm{~b}$.

16. 3 Id. $\S 2214 \mathrm{~d}$.

17. Common Law Procedure Act, $1854,17 \& 18$ Vicr. c. $125, \S 27$.

18. 3 Chamberlayne, op. cit. supra note $14, \$ 2214$ (d).

19. 7 WIGMORE, op. cit. supra note $2, \S 2016 \mathrm{n} .1$; $\$ 2008 \mathrm{n} .1$. Note however, Georgia: Smith v. State, $77 \mathrm{Ga} .705$ (1886), authorizes expert comparison. See also GA. CODE ANN. \$38-708 (1954). Rhode Island: 7 WxGMORE, op. cit. stepra note 2, $\$ 2008$ n.1 states "not allowed by the statute"-probably a typographical error (not should be now) ; R.I. GEN. LAwS c. 538, \&14 (1938). But see In re Astolas' Estate, 273 Mich. 189, 262 N.W. 766 (1935) (expert testimony inadmissible on issue of genuineness of a signature made by mark).

20. See text at pp. 677-78 infra.

21. See UNIFORM RULES OF EVIDENCE rules 67-71. 
knowledge of the alleged author's handwriting by observing genuine specimens which have been introduced into evidence and which they juxtapose with the disputed writing in court. ${ }^{22}$ The non-expert may not so juxtapose established standards since the jury is as qualified to do this as is he. ${ }^{23}$ The non-expert testifies by comparing his memory of other writings of the alleged author with the disputed writing. ${ }^{24}$ Sometimes the non-expert may be allowed to refresh his memory by being shown a genuine writing he has seen before, but his testimony still is supposed to be from his memory. ${ }^{25}$

The non-expert's testimony carries little weight, ${ }^{26}$ and it is easily discredited. His opinion is based only on the general appearance of the writing ${ }^{27}$ since he ordinarily knows nothing about the science or mechanics of handwriting. His memory of the writing previously seen is fallible and generally inaccurate. Psychological experiments indicate that the details of a mental image fade first and quite rapidly. It is the main outline or schemata which is retained; the details are changed or omitted. ${ }^{28}$ As a result, the non-expert may be discredited on cross examination by questions which he ordinarily will be unable to answer such as: "Does this writing you remember have a forward or backward slant?"; "Is the 'A' formed by beginning the stroke at the top or bottom of the letter?"; "At what angle is the ' $T$ ' crossed?" Testimony of genuineness by the non-expert therefore generally carries less weight than comparison by juxtaposition of the genuine specimen with the disputed writing by either the trier of fact or a qualified expert.

In fact, the non-expert's testimony has been shown to be of comparatively little evidentiary value. An experiment on identification of handwriting indicates that non-experts attempting to identify genuine signatures on the basis of their memory of the author's handwriting have a very low percentage $(11 \%)$ of accuracy. The same experiment indicates that comparison by means of juxtaposing the disputed writings with a set of genuine specimens is more accurate. By means of this latter method, the non-experts employed in the experiment scored a significantly higher but still unsatisfactory percentage $(37 \%)$ of accuracy. ${ }^{29}$

22. See Flickema v. Henry Kraker Co., 252 Mich. 406, 233 N.W. 362 (1930); Poole v. Beller, 104 W. Va. 547, 140 S.E. 534 (1927).

23. In re O'Connor's Estate, 101 Neb. 617,164 N.W. 570 (1917).

24. See Hershberger v. Hershberger, 345 Pa. 439, 29 A.2d 95 (1942) ; In re Diggins' Estate, 68 Vt. 198, 34 At1. 696 (1896).

25. 7 WIGMORE, op. cit. supra note $2, \S 2007$. Other exceptions to the rule forbidding the non-expert to testify from genuine standards presented to him in court are: (1) A non-expert who has seen the disputed document now lost but did not then know the author of it may compare his memory of it with an established genuine standard. 7 Id. $\$ 2005$. (2) The possessor of ancient documents may compare them in court with the disputed writing. 7 Id. $\$ 2006$.

26. See Roberts v. McCown, 288 Ky. 543, 156 S.W.2d 840 (1941) ; Hartford Fire Ins. Co. v. Webb, $281 \mathrm{Ky} .276,135$ S.W.2d 883 (1940).

27. Inbau, Lay Witness Identification of Handwriting, 34 ILL. L. REv. 433, 442 n.15 (1939); BAKER, LAw of DISPUTED AND FORGED Documents $\$ 22$ (1955).

28. Munn, Psychology 207-08 (1951).

29. Inbau, supra note 27. For the purpose of testing identification from memory, professors of the law faculty of Northwestern University and their secretaries at- 
Comparison by juxtaposition can be done only by the trier of fact or by an expert witness since any conclusions drawn from comparison by the ordinary witness would fall within the rule excluding opinion evidence. ${ }^{30}$ For this reason, any witness who testifies on this basis must have special skill, knowledge or experience in the field of handwriting so that his opinion and his explanation of the reasons behind it will contribute something in the search for truth over and beyond what the trier of fact could discern for himself. ${ }^{31}$ Whether a witness is so qualified is a matter for the trial court's discretion. 32

In most cases, a witness is accepted as an expert if he has an occupation which involves scrutinizing and accepting signatures or handwriting. Bank employees, ${ }^{33}$ registrars of deeds, ${ }^{34}$ postmasters, ${ }^{35}$ and handwriting teachers ${ }^{36}$ have been permitted to give their opinions based on comparison in court. Ordinarily, these persons know little or nothing about scientific handwriting analysis. ${ }^{37}$ They are not handwriting analysts with the training or experience of the professional document examiner. Even when they admit their real lack of knowledge of the science of handwriting under crossexamination, some courts still hold them competent to give their opinion. ${ }^{38}$

The other type of witness admitted as an expert is the handwriting analyst. Through study and experience, such a witness is familiar with the art and science of handwriting analysis. This is the study of the unconscious, automatic motion habits which form a person's handwriting characteristics. ${ }^{39}$ Handwriting has class characteristics and individual

tempted to identify the genuine signatures of the law professors in a set of four signatures: a genuine specimen, a free-hand forgery, a tracing, and a spurious specimen (one made without any attempt at imitation). For the purpose of testing identification on the basis of comparing genuine standards with the unknown writings, a random selection of lay persons were provided with the sets of four signatures, as above, plus a set of six genuine specimens. The same experiment was performed with bank employees of several years' experience cashing checks or paying withdrawals from savings accounts. The ordinary lay persons had an average accuracy of $37 \%$ while the bank employees had an average accuracy of only $43 \%$, a statistically insignificant difference.

30. MCCORMICK, EvIDENCE § 172 (1954); 7 WIGMORE, op. cit. supra note 2, § 1997. The wisdom of this rule may be perceived from the results of the experiment described in the preceding footnote--the ordinary lay person is no more accurate than the ordinary juror and therefore can add nothing by his testimony. 6 (1927).

31. McCormick, Evidence $\S 13$ (1954); Gavin v. Kniffen, 82 Colo. 448, 261 Pac.

32. McCormick, Evidence $\$ 13$ (1954); 7 WIGMore, op. cit. supra note 2, § 2012. See Simon v. Larson, 207 Minn. 605, 292 N.W. 270 (1940); O’Kelley v. Mutual Life Ins. Co., 197 S.C. 109, 14 S.E.2d 582 (1941).

33. Fekete v. Fekete, 323 I11. 468, 481, 154 N.E. 209, 214 (1926) ; Keeney v. Arp De La Gardee, 212 Iowa 45, 47, 235 N.W. 745, 746 (1931); Adams v. Ristine, 138 Va. 273, 122 S.E. 126 (1924); Johnson v. Bee, 84 W. Va. 532, 100 S.E. 486 (1919).

34. Kornegay v. Kornegay, 117 N.C. 242, 23 S.E. 257 (1895).

35. State v. Parsons, 140 Kan. 157, 33 P.2d 1096 (1934).

36. First Galesburg Nat'l Bank \& Trust Co. v. Federal Res. Bank, 295 Ill. App. 524, 15 N.E.2d 337 (1938).

37. See note 11 supra.

38. Fenias v. Reichenstein, 124 N.J.L. 196, 11 A.2d 10 (Sup. Ct. 1940); Tower v. Whip, 53 W. Va. 158, 44 S.E. 179 (1903). (1950).

39. Appel, Advances in Analysis of Questioned Documents, 38 GEo. L.J. 385, 386 
characteristics. Class characteristics result from the system of writing which the writer employs while individual characteristics are a result of the writer's muscular control, coordination, age, health, nervous temperament, frequency of writing, personality and character. ${ }^{40}$ No two persons write exactly alike, ${ }^{41}$ and no reproduction of a handwritten document can duplicate completely all the details of the original writing.42 The professional examiner is trained to detect these individual peculiarities. The microscope $^{43}$ and camera ${ }^{44}$ reveal minute details which escape the untrained and unaided observation. Ultraviolet light may reveal erasures and eradications and makes possible reading what was originally written. ${ }^{45}$ By chemical analysis of the ink or paper, it can be determined in many cases when the writing was executed..$^{46}$ Much of the expert's testimony is not actually an opinion but a statement of physical facts which is accepted as direct evidence. 47 The expert's statement of his conclusion on the authorship is accompanied by a detailed explanation of the reasons supporting it. ${ }^{48} \mathrm{He}$ generally illustrates his testimony with specially prepared enlarged photographs. ${ }^{49}$ For these reasons, the truly qualified expert is an invaluable witness in handwriting cases.

The experiment mentioned above ${ }^{50}$ indicates that these persons have an accuracy of 90 per cent. On the other hand, the same experiment showed that bank employees and others commonly accepted as experts, absent the special training just described, give opinions of little or no greater reliability' than any other non-expert such as the judge or members of the jury. ${ }^{51}$ Like any other non-expert, their opinions probably are based on the general appearance of the writing. ${ }^{52}$ Their greater experience with writing does not seem to increase the accuracy of their opinions. Perhaps the explanation for this lies in the fact that their identification of the handwriting is in a large part based on other considerations. For example, bank tellers generally do not pay on a check on the basis of their examination of the handwriting alone but also rely on their recognition or the general appearance of the person presenting the check..$^{53}$

40. Hilton, The Detection of Forgery, 30 J. CRIM. L., C. \& P.S. 568 (1940).

41. BAKER, op. cit. supra note $27, \$ 14$.

42. Id. $\S 15$; Hilton, supra note 40 , at 599 .

43. BAKË, op. cit. supra note $27, \S \S 24-29$.

44. Id. $\S \S 30,31$.

45. Id. $\S \S 32-34$; OsBoRN, op. cit. supra note 1 , at 159 .

46. Appel, supra note 39, at 389-94.

47. See Fekete v. Fekete, 323 I11. 468, 483, 154 N.E. 209, 214 (1926) ; 3 Chas BERLAYNE, op. cit. supra note $14, \S 2224$.

48. 7 Wigmore, op. cit. supra note $2, \S 2014$.

49. Howard v. Russel, 75 Tex. 171, 12 S.W. 525 (1889); Hancock v. Snider, 101 W. Va. 535, 133 S.E. 131 (1926).

50. See note 29 supra.

51. Inbau, supra note 27 , at 439.

52. See note 27 supra.

53. See Keeney v. Arp De La Gardee, 212 Iowa 45, 48, 235 N.W. 745, 746-47 (1931). Interview with John H. Stewart, Assistant Treasurer, First Pennsylvania Bank, Philadelphia, Pa., Dec. 19, 1955. 
Perhaps the testimony of persons untrained in handwriting analysis on the basis of comparison by juxtaposition should be excluded since the jury is probably as competent as these witnesses in comparison..$^{54}$ Furthermore, the jury may be unduly influenced by the testimony of these witnesses. This is especially true in smaller communities where the person testifying, such as the local banker, is a well known and respected figure. $\mathrm{He}$ is nearly always called in disputed document cases since his absence may raise suspicions in the minds of the jury. ${ }^{55}$ When cross-examined, the lack of expert qualification of these witnesses will be exposed to the jury and will affect the weight of their testimony even though it may not affect its admissibility. ${ }^{56}$ These alleged experts in handwriting generally will be unable to recognize the system or to point out any of the characteristics of the disputed writing and will be unfamiliar with the methodology and terminology of the professional examiner. ${ }^{57}$ If there is also an expert document examiner in the case, permitting bankers and other such witnesses to testify probably will not affect the result. The testimony of the handwriting analyst will generally be more convincing since he is able to explain and illustrate the reasons behind his opinion..$^{58}$ However, if funds or inaccessibility prevent obtaining handwriting analysts, ${ }^{59}$ substantial harm may result regardless of the effectiveness of cross-examination since the jury still may place undue weight on the opinion of these "experts" when, in fact, their own opinion is substantially as reliable.

\section{Admissibility and Proof of Genuine Specimens}

As a basis for comparison, the handwriting style of the purported author must be proved by introducing into evidence genuine specimens of that handwriting as standards. It is apparent that the value of comparison evidence depends heavily on the reliability of the specimens introduced as standards. In order to form a valuable opinion, the handwriting of the alleged author should be represented by an adequate number of genuine specimens. Reflective of this is the fact that the careful professional document examiner, when consulted for an opinion, often makes an independent search for specimens in order to get as complete and fair a sampling of the alleged author's handwriting as possible. ${ }^{60}$ Specimens from such sources as the pleadings, depositions, voters registration cards and income tax re-

54. In McCormick's opinion these "part-time" experts, as he calls them, (bank cashiers, etc.) are much superior to the layman. No authority is cited nor any reason given. McCormick, Evidence § 172 (1954).

55. See note 11 supra.

56. Fenias v. Reichenstein, 124 N.J.L. 196, 11 A.2d 10 (Sup. Ct. 1940); Tower v. Whip, 53 W. Va. 158, 44 S.E. 179 (1903).

57. For suggestions on how to bring out these facts on cross-examination, see OsBoRN, op. cit. supra note 1 , at 157-58.

58. See Fekete v. Fekete, 323 I11. 468, 483, 154 N.E. 209, 214 (1926); Murphy v. Murphy, 146 Iowa 255, 262, 125 N.W. 191,193 (1910); 7 WIGMoRE, op. cit. supra note $2, \S 2014$.

59. See OsBorn, op. cit. supra note 1 , at $416-19$ for a suggested solution.

60. See note 11 sispra. 
turns help the expert guard against the possibility of his own client misleading him with insufficient or inaccurate standards. ${ }^{61}$

The courts have recognized the necessity for adequate and reliable specimens of the alleged author's handwriting. Today the rule in practically every jurisdiction, by statute or decision, is that any specimen which is admitted ${ }^{62}$ or proved ${ }^{63}$ to be genuine to the satisfaction of the court is admissible for purposes of comparison. ${ }^{64}$ The number of genuine specimens is a matter of the trial judge's discretion. He must admit enough to give a sufficiently wide basis for comparison, ${ }^{65}$ and he may restrict the introduction of additional specimens as standards when the number already in evidence is adequate. 68

For a long time, however, free admission of genuine specimens was not permitted for two main reasons. The courts feared that a party could mislead the jury by proposing an unfair selection of specimens, ${ }^{67}$ and they were concerned that the process of proving the genuineness of proposed specimens would delay the trial and raise collateral issues which might divert and confuse the jury. ${ }^{68}$ To minimize these dangers, some states admitted only those specimens which were conceded by the opponent to be genuine; ${ }^{69}$ others limited the standards for comparison to those writings already in the case for some other purpose $;^{70}$ while others admitted those specimens which the judge had determined to be genuine. ${ }^{71}$ Although successful in minimizing the problems aimed at, the first two rules were arbitrary and unduly restrictive. ${ }^{72}$ Today, the third rule has been adopted in the overwhelming majority of American jurisdictions. ${ }^{73}$

Unfair selection of specimens by one party still may be possible under this majority rule even though the trial judge must admit enough to give

61. Ibid.

62. "Admitted" means a judicial admission. 7 WIGMORE, op. cit. supra note 2, $\$ 2021$. There can also be an admission by silence in failing to object. In re Goldberg, 91 F.2d 996 (2d Cir. 1937); Mitchell v. First Nat'l Bank, 40 Idaho 463, 234 Pac. 154 (1925); State v. Van Tassel, 103 Iowa 6, 72 N.W. 497 (1897); Popalis v. Yanchura, 114 Pa. Super. 204, 173 At1. 743 (1934).

63. See text at note 78 infra.

64. See BAKER, op. cit. supra note $20, \S 69$ for statutory comparison. The only jurisdiction which limits specimens to those admitted or treated as genuine and does not permit them to be proved genuine by other evidence is Oregon. ORE. Rev. STAT. $\S 42.070$ (1953), State v. Tice, 30 Ore. 457, 48 Pac. 367 (1897), State v. Branton, 49 Ore. 86, 87 Pac. 535 (1906).

65. Mutual Life Ins. Co. v. Suiter, 131 N.Y. 557, 29 N.E. 822 (1892).

66. Crane v. Dexter, Horton \& Co., 5 Wash. 479, 32 Pac. 223 (1893). See KY. Rav. STAT. $\$ 422.120$ (1953).

67. 7 WIGMORE, op. cit. supra note $2, \S 1999$.

68. 7 Id. $\S 2000$.

69. E.g., Ore. Rev. Stat. $\$ 42.070$ (1953), State v. Tice, 30 Ore. 457, 48 Pac. 367 (1897); Calkins v. State, 14 Ohio St. 222 (1863).

70. E.g., Miles v. Loomis, 75 N.Y. 296 (1878).

71. See cases cited in note 73 infra.

72. 7 WIGMORE, op. cit. supra note 2, §\$ 1999, 2000.

73. See, e.g., State v. Thompson, 80 Me. 194, 13 At1. 892 (1888); Costello v. Crowell, 139 Mass. 588, 2 N.E. 698 (1885); Omohundro v. State, 172 Tenn. 48, 109 S.W.2d 1159 (1937), 15 TENN. L. Rev. 25 '(1938); Rowell v. Fuller's Estate, 59 Vt. 688, 10 Atl. 853 (1887). 
a wide basis for comparison. ${ }^{74}$ However, unfair selection is a possibility in any case of proffered evidence, but this has never been considered a ground for excluding testimony in any other instance. ${ }^{75}$ Furthermore, if one party does present an incomplete or misleading set of standard specimens, the opposing party may qualify the impression created by introducing further specimens. ${ }^{76}$

The problem of collateral issues is met, of course, by vesting the judge with the sole power to decide the preliminary fact of genuineness. ${ }^{77}$ The standard of proof required is such clear and convincing evidence that the judge may find the standard genuine as a matter of law. ${ }^{78}$ Ordinarily, any direct or circumstantial evidence is admissible for this purpose, ${ }^{79}$ but the genuineness of the specimens may not be proved by comparison with other standards. ${ }^{80}$ Some jurisdictions do not permit any opinion evidence for this purpose, ${ }^{81}$ out of either a distrust of the reliability of such evidence ${ }^{82}$ or a desire to avoid further collateral issues. ${ }^{83}$ This is a sensible approach since opinion evidence of non-experts is of the least probative value, ${ }^{84}$ and the process of comparison by the trier of fact with the aid of expert testimony, while highly reliable, ${ }^{85}$ inherently contains the possibility of compounding errors of judgment.

In a few jurisdictions, the genuineness of a specimen in criminal cases is decided only preliminarily by the judge. ${ }^{86}$ If he decides that the specimen is not genuine, he may exclude it; but if there is sufficient evidence of its genuineness, he sends the issue to the jury. In these states, possible

74. See notes 64 and 65 supra.

75. See Lyon v. Lyman, 9 Conn. 55 (1831) ; 7 WIGMORE, op. cit. supra note 2 , § 1999; SECOND REPORT OF HER MAJESTY'S COMMISSIONERS 25-26 (1853).

76. See note 65 supra.

77. See note 73 sitpra.

78. Wilson v. Scroggs, 85 Colo. 537, 277 Pac. 784 (1929); Brantley v. State, 84 Fla. 649, 94 So. 678 (1922); Cook v. Moecker, 217 I1l. App. 479 (1920); Sankey v. Cook, 82 Iowa 125, 47 N.W. 1077 (1891); Clark v. Douglass, 5 App. Div. 547, 40 N.Y. Supp. 769 (3d' Dep't 1896).

79. See People v. Molineux, 168 N.Y. 264, 328, 61 N.E. 286, 307 (1901). As to applicability of the "return letter" doctrine, compare McKeone v. Barnes, 108 Mass. 344 (1871), with Manning v. State, 37 Tex. Crim. 180, 39 S.W. 118 (1897).

80. 7 WIGMORE, op. cit. supra note $2, \S 2020$.

81. By statute: Ky. REv. STAr. $\$ 422.120$ (1953). By decision: State v. Wickett, 230 Iowa 1182,300 N.W. 268 (1941); Commonwealth v. Tucker, 189 Mass. 457,76 N.E. 127 (1905); Fullam v. Rose, 181 Pa. 138, 37 Atl. 197 (1897) ; Eborn v. Zimpleman, 47 Tex. 503 (1877). But see Whorton v. State, 69 Tex. Crim. 1, 152 S.W. 1082 (1913).

82. Cf. Renner v. Thornburg, 111 Iowa 515, 82 N.W. 950 (1900).

83. Plymouth Sav. \& Loan Ass'n v. Kassing, 72 Ind. App. 1, 125 N.E. 488 (1919).

84. See text at note 29 supra.

85. See text at note 50 supra.

86. Chisholm v. State, 204 Ala. 69, 85 So. 462 (1920) ; State v. Ryno, 68 Kan. 348, 74 Pac. 1114 (1904); Commonwealth v. Tucker, 189 Mass. 457, 76 N.E. 127 (1905); State v. Hastings, 53 N.H. 452 (1873); People v. Molineux, 168 N.Y. 264, 61 N.E. 286 (1901). 
confusion to the jury is not considered to outweigh the defendant's constitutional right to a trial by jury ${ }^{87}$ or the desirability of the jury's traditional role as the final arbiter of the facts. ${ }^{88}$

It is doubtful if vesting sole power in the judge to find the preliminary fact of genuineness of a proposed standard denies the defendant his trial by jury. The constitutional right is that a jury should decide the ultimate question of his guilt or innocence. Whether it is the judge or the jury who decides the preliminary questions of fact which arise in relation to the admissibility of evidence is grounded in other considerations. ${ }^{89}$ The generally accepted analysis is that preliminary questions of fact which determine the competency of proposed evidence, for example, dying declarations, are for the judge alone. Ordinarily, the jury would not be able to erase the evidence from their minds if they did not find it competent. Moreover, the jury is generally more interested in reaching a verdict in accordance with what they believe is true than in performing the intellectual gymnastic of disregarding evidence for the sake of enforcing the long term policies of evidence law. ${ }^{90}$ On the other hand, preliminary questions determining the relevancy of the offered evidence may safely be left to the jury. The jury understands relevancy and is willing to observe it since it goes only to probative pertinence. ${ }^{91}$ Whether the determination of the genuineness of proposed specimens is a problem of the competency of the evidence or of its relevancy is a close question. ${ }^{92}$ It is unlikely that the jury would experience much difficulty in disregarding specimens they found not to be genuine for purposes of their own comparison. On the other hand, it may prove difficult to evaluate the expert's opinion if the jury must disregard some of the specimens which were used by the expert in stating his opinion.

Moreover, the majority rule of leaving this question to the judge alone has many advantages. It promotes simplicity in trial administration by leaving the jury unencumbered with legal definitions and collateral questions. Since it is impossible to know what the jury decided after a general verdict, rulings on the question by the judge alone simplify the problem of arguing a motion for a new trial or an appeal. Presenting special questions to the jury may be effective in this regard, but this may impede

87. See People v. Molineux, supra note 86.

88. See Chisholm v. State, 204 Ala. 69, 85 So. 462 (1920); Commonwealth v. Tucker, 189 Mass. 457, 76 N.E. 127 (1905); State v. Hastings, 53 N.H. 452 (1873).

89. See Maguire \& Epstein, Preliminary Questions of Fact in Determining the Admissibility of Evidence, 40 HARV. L. REv. 392 (1926) ; Morgan, Functions of Judge and Jury in the Determination of Preliminary Questions of Fact, 43 HARv. L. REv. 165, 173 n.20, 187-89 (1929); McCormick, The Procedure of Admitting and Excluding Evidence, 31 TEXAs L. REv. 128, 143-45 (1952); Wyzanski, $A$ Trial Judge's Freedom and Responsibility, 65 HARV. L. REv. 1281, 1285 (1952).

90. McCoraick, EndDENCE $\$ 53$ (1954); McCormick, The Procedure of Admitting and Excluding Evidence, 31 TexAs L. REv. 128, 143 (1952).

91. Id. at 146.

92. Professor Morgan believes that the genuineness of standards for handwriting comparison is a competency problem since the jury must be protected from undue confusion and complication of issues and the defendant from unfair surprise. Morgan, Functions of Judge and Jury in the Determination of Preliminary Questions of Fact, 43 HaRv. L. REv. 165, 173 n. 20 (1929). 
rather than assist the jury in reaching a verdict. The jury may be able to reach a general verdict by unanimous vote but may not be unanimous on questions relating to it. ${ }^{93}$ Moreover, the timid or indolent judge may accept this invitation to shirk his responsibilities and fail to scrutinize carefully the proposed specimens when the final determination rests with the jury. ${ }^{94}$

Regardless of whether the specimen is genuine, it may not be admissible on other grounds. A genuine specimen may be excluded if the content of the writing is inflammatory or prejudicial. ${ }^{95}$ Similarly, a reproduction of a genuine specimen may be rejected if there is insufficient proof of its physical accuracy. Letter-press copies, now rare, were never competent evidence of handwriting. ${ }^{96}$ Photolithic, $^{97}$ photostatic, ${ }^{98}$ and photographic ${ }^{99}$ copies are generally admitted after an affirmative showing of the exactness of reproduction. Ordinarily, the testimony of the expert document examiner that the reproductions were made under his supervision and in his presence, and in his opinion are suitable, is a sufficient accounting for the authenticity and scientific accuracy of the copy. ${ }^{100}$ The reproductions are submitted to the jury with the caution that some of the dynamic characteristics of the handwriting are lost in the process. ${ }^{101}$

Another rule of exclusion is that writings made post litem motam, i.e., after the controversy arose, may not be proposed by their author ${ }^{102}$ unless they were executed in the ordinary course of business or under circumstances which negative all idea that they were made for the purpose of being used as evidence in his favor. ${ }^{103}$ Writings executed for the sole purpose of creating standards are viewed with suspicion since a party should not be allowed to manufacture evidence in his own favor. ${ }^{104}$ There is a strong likelihood that the specimens will be executed by the party with intent to confuse by intentionally disguising his handwriting. ${ }^{105}$

93. See Maguire \& Epstein, Preliminary Questions of Fact in Determiting the Admissibility of Evidence, 40 HARv. L. REv. 392 (1926).

94. Compare MCCormick, EVtdence, $\$ 112$ (1954).

95. Gambrill v. Schooley, 95 Md. 260 , 52 At1. 500 (1902) ; Hatch v. State, 6 Tex. Crim. 384 (1879); see N.M. STAT. ANN. \$ 20-2-15 (1953).

96. See Cohen v. Teller, $93 \mathrm{~Pa} .123$ (1880).

97. Geer v. Missouri Lumber \& Mining Co., 134 Mo. 85, 34 S.W. 1099 (1896).

98. Moncur v. Western Life Indemnity Co., 269 Pa. 213, 112 Atl. 476 (1921).

99. Howard v. Russel, 75 Tex. 171, 12 S.W. 525 (1889); Hancock v. Snider, 101 W. Va. 535, 133 S.E. 131 (1926). 1946).

100. Cf. Thomas v. State $e x$ rel. Comm'rs of Land Office, 172 P.2d 973, 976 (Okla.

101. See note 98 supra.

102. By statute: Ky. REv. Stat. $\$ 422.120$ (1953) ; Mich. Stat. ANn. $\$ 27.900$ (1938) ; N.J. REv. STAT. §2A :82-1 (1951); N.M. STAT. ANN. \$20-2-15 (1953). By decision: Travers v. Snyder, 38 Ill. App. 379 (1890); Johnson y. Crown Finance Corp., 222 S.W.2d 525 (Mo. App. 1949); Sanderson v. Osgood, 52 Vt. 309, 312 (1880) (dictum).

103. See note 102 supra; University of Illinois v. Spalding, 71 N.H. 163, 51 Atl.

731 (1901); State v. Hopkins, 50 Vt. 316 (1877).

104. See BAKER, op. cit. supra note 27 , at 85-86.

105. Johnson v. Crown Finance Corp., 222 S.W.2d 525, 530 (Mo. App. 1949). 
Writings made post litem motam, although inadmissible in favor of the party making them, are admissible against him. ${ }^{106}$ Accordingly, writings made at the opponent's request may be introduced as standards. ${ }^{107}$ Usually this request is made ${ }^{108}$ and the opponent must ordinarily execute the requested specimens. ${ }^{109}$ To obtain reliable standards by this method, a number of signatures should be written under observation to prevent any attempt by the writer to disguise his style. The best standards can be obtained if the signatures are executed on similar paper, on separate sheets in the same location on the sheet, and with the same implement as the disputed signature.110 Although the witness may attempt to disguise his hand, this can be detected by comparison with other genuine specimens so that the witness' effort will only result in discrediting his own general credibility.

Thus far the discussion of the admissibility of specimens has centered on their reliability and general competency. A separate issue of admissibility arises in a few jurisdictions. Although specimens are ordinarily offered to prove that the disputed document was or was not written by the purported author, in many cases, it may be desirable to prove in addition to this that the writing was executed by some other specific person. Most jurisdictions do permit the introduction of an alleged forger's handwriting to prove that he rather than the purported author actually executed the writing in question. ${ }^{111}$ In the few jurisdictions which do not permit this, ${ }^{112}$ judicial resistance to comparison evidence in general is high. The decisions excluding specimens offered for this purpose are based either on an overly narrow reading of the statute permitting comparison evidence ${ }^{113}$ or on the ground that collateral questions are introduced.114 Since proof that some other specific person executed the writing in question is convincing proof of the fact that the purported author did not execute the writing, it is doubtful that proof of actual authorship should be considered collateral to the

106. People v. Molineux, 168 N.Y. 264, 61 N.E. 286 (1901).

107. Allen v. Gardner, 47 Kan. 337, 27 Pac. 982 (1891); Sprouse v. Commonwealth, 81 Va. 374 (1886).

108. See note 11 supra.

109. A witness may be upheld in refusing to write when requested if the disputed writing was executed before his handwriting style matured, Williams v. Riches, 77 Wis. 569,46 N.W. 817 (1890), or if he asserts his privilege against self-incrimination, People v. Molineux, 168 N.Y. 264, 333, 61 N.E. 286, 309 (1901) ; Beltran v. Samson, 53 Phil. 570 (1929) ; 8 WrGMore, op. cit. supra note $2, \$ 2264$. However, if the defendant in a criminal case takes the stand in his own defense, he may be compelled to write. Hall v. State, 171 Ark. 787, 286 S.W. 1026 (1926); Bradford v. People, 22 Colo. 157, 43 Pac. 1013 (1896).

110. Hilton, Procuering Handweriting Specimens During Cross-Examination, 28 CoNN. B.J. 168 (1954).

111. See, e.g., Wooldridge v. State, 49 Fla. 137, 38 So. 3 (1905) ; People v. Truck, 170 N.Y. 264, 63 N.E. 281 (1902) ; People v. Molineux, 168 N.Y. 264, 61 N.E. 286 (1901).

112. Strong v. Abner, 268 Ky. 502, 105 S.W.2d 599 (1937) ; Johnson v. Crown Finance Corp., 222 S.W.2d 525 (Mo. App. 1949); Franklin v. Franklin, 90 Tenn. 150, 16 S.W. 557 (1890); cf. Coppock v. Lampkin, 114 Iowa 664, 87 N.W. 665 (1901).

113. Strong v. Abner, sutpra note 112.

114. Johnson v. Crown Finance Corp., 222 S.W.2d 525 (Mo. App. 1949). 
issue of authentication. When a New York court excluded specimens offered for this purpose, ${ }^{115}$ the result was changed by statute. ${ }^{116}$

\section{Cross-Examination}

Counsel trying a case in which comparison evidence is introduced must carefully weigh the strategy he will use in cross-examination. It is an important tactical decision whether to cross-examine the highly skilled analyst at all. ${ }^{117}$ Since he is likely to know more about the technical matter involved than the lawyer, inquiries into the basis of his opinion may strengthen the witness' testimony rather than weaken it. ${ }^{118}$ However, the qualifications of the alleged expert such as the banker or postmaster may well be explored, at least to help the trier of fact to evaluate his opinion, even if his testimony cannot thereby be stricken from the record. ${ }^{119}$ The qualifications of the analyst may also be questioned if the cross-examiner has advance information on the subject. ${ }^{120}$ The analyst's testimony might be weakened by questions which reveal that he has not kept abreast of new techniques of analysis or has had little experience with an unusual problem presented by the document in dispute. ${ }^{121}$

If it is decided not to question the expert's qualifications or his opinion directly, several avenues are open to the examiner. First of all, it is an accepted and generally permitted practice to attempt to impeach the witness by questioning him as to his fees or charges. ${ }^{122}$ If the fee is excessive or contingent on the outcome of the litigation, a strong suggestion of bias may be raised. ${ }^{123}$ Another available means of impeachment is to question the expert about a mistake made in a former trial. The cases disagree on the permissibility of this line of questioning, ${ }^{124}$ and the relevancy of such an inquiry is doubtful. A mistake in an opinion given in a prior unrelated case does not really affect the value of the expert's present opinion since its persuasiveness depends on the soundness of the reasons supporting it. Moreover, the question seems likely to confuse the jury by presenting the collateral issue of whether the expert was mistaken.

There are two other generally practiced modes of testing the expert's opinion. The first method is to show the same specimen to several wit-

115. Peck v. Callaghan, 95 N.Y. 73 (1884).

116. N.Y. STAT. 1888 , c. 555 as cited in 7 WIGMore, op. cit. supra note $2, \S 2016$

n.1; People v. Murphy, 135 N.Y. 453, 32 N.E. 138 (1892).

117. See Cornelius, Cross-Examination of Witnesses 246-56 (1929).

118. OSBORN, op. cit. supra note 1 , at 154 .

119. See text at note 38 supra.

120. See note 11 supra.

121. See Keys v. Keys, 23 Tenn. App. 188, 129 S.W.2d 1103 (1939).

122. See Butman v. Christy, 197 Iowa 661, 198 N.W. 314 (1924).

123. OsBorn, op. cit. supra note 1, at 219-20. Furthermore, it is not ethical for a lawyer to pay a contingent fee to a witness. DRINKER, LEGAL ETHICS 86 (1953).

124. Compare Hoag v. Wright, 174 N.Y. 36, 66 N.E. 579 (1903) (permitted to ask expert about mistake at former trial), with In re Gunerson's Estate, 174 Wash. 462, 24 P.2d 1070 (1933) (not permitted). 
nesses in the hope that they will give conflicting opinions. ${ }^{125}$ In the use of this technique it is not necessary to establish the genuineness of the specimen used since its effect lies in showing disagreement among the experts. The second method, which does require special collateral proof of genuineness, is to show the witness a writing which is a provable forgery in the hope that he will declare it to be genuine. ${ }^{126}$ There are many variations on this method. For example, counsel may write his own name both righthanded and left-handed and then ask the witness either to tell whether they were written by the same person or to tell which is written left-handed. Another often employed variation is to mingle genuine and spurious specimens and ask the expert to declare which are the genuine writings. ${ }^{127}$

These varied uses of spurious specimens may effectively discredit the expert's opinion, but many courts do not permit his opinion to be tested in this way. In some states this technique is barred on the ground that the statute permitting comparison by expert witnesses specifies that only specimens admitted or proved to be genuine may be used.128 In other jurisdictions, the use of spurious writings on cross-examination is prohibited for any or all of the following reasons: collateral questions of proving the forgeries are introduced; the issues are multiplied; the minds of the jury are diverted; the jury may be confused; and the witness is put to an unfair disadvantage. ${ }^{129}$ For similar reasons, some courts do not permit the use of specimens not already in evidence. ${ }^{130}$

Prohibiting the use of spurious specimens on the basis of statutory construction is an unfortunate result, since the statutes were enacted to overcome previous judicial restrictions on the use of specimens for comparison purposes. ${ }^{131}$ The contentions that the trial is impeded and the jury may be confused by collateral issues are not serious objections. These were first advanced to limit the introduction of specimens for comparison purposes to those already in the case or to those admitted to be genuine. ${ }^{132}$ To the extent that these limitations were imposed to prevent confusing the jury, the reasons behind them have lost their validity under the rule permitting proof of genuineness to the judge alone. ${ }^{133}$ The trial will not be impeded since the false specimens used on cross-examination ordinarily are prepared during the trial so that the one who made them is readily

125. 7 WIGMORE, op. cit. supra note $2, \S 2015$.

126. Ibid.

127. Browning v. Gosnell, 91 Iowa 448, 456, 59 N.W. 340, 343 (1894); Hoag v. Wright, 174 N.Y. 36, 66 N.E. 579 (1903).

128. Fourth Nat'l Bank v. McArthur, 168 N.C. 48, 84 S.E. 39 (1915); Wilmington Sav. Bank v. Waste, 76 Vt. 331, 57 Atl. 241 (1904).

129. See McArthur v. Citizens' Bank, 223 Fed. 1104 (4th Cir. 1915) ; Underwood v. Quantic, 85 Kan. 111, 116 Pac. 36 (1911) ; Fourth Nat'l Bank v. McArthur, supra note 128.

130. Rose v. First Nat'1 Bank, 91 Mo. 401, 3 S.W. 876 (1886) ; Mitchell v. First Nat'l Bank, 40 Idaho 463, 467, 234 Pac. 154, 156 (1925) (dictum).

131. See text at notes $69-71$ supra.

132. See text at note 68 supra.

133. See text at notes 71,73 supra. 
available to prove their character. ${ }^{134}$ Confessedly, this technique may take unfair advantage of the witness, but protecting him from impeachment by this method would not seem to be a relevant consideration. If necessary, the case might be continued to enable the witness to analyze the specimen. Actually, a cautious and skilled expert will not hazard an opinion on specimens which he sees for the first time. ${ }^{135}$ The essence of his approach is a slow, careful analysis employing the camera, microscope, ultraviolet light and the other resources of the modern laboratory. ${ }^{136}$ The expert witness who will give his opinion without this searching examination should be exposed since this may be indicative of the value of his prior testimony on the disputed document.

Restricting the use of spurious signatures is a serious loss to both the cross-examiner and the court seeking the truth. ${ }^{137}$ Cross-examination has long been regarded as an important safeguard of the accuracy and completeness of testimony. ${ }^{138}$ The cross-examiner should be permitted to use any device within his ingenuity and the bounds of propriety to expose the expert who is careless and inept enough to hazard opinions on insufficient investigation. "It is better to take a little time to see whether the opinion of the witness is worth anything, rather than to hazard life, liberty or property upon an opinion that is worth nothing." 139

\section{Weight OF THE EXPERT'S TESTIMONY}

There is no uniformity in the attitude of the various jurisdictions toward the weight to be attached to expert handwriting testimony, and the decisions seem to make no distinction between the handwriting analyst and the questionable "expert" such as the banker or postmaster. ${ }^{140}$ In some jurisdictions it is still considered proper to disparage expert testimony in the charge to the jury by telling them that it is "unsafe" 141 or "most unsatisfactory." ${ }^{142}$ A neutral position is observed in other courts where it is said that the weight to be attached to the expert's testimony is "for the jury," 143 or it is fairly pointed out that the weight of opinion testimony depends largely on the character of the witness, his opportunity for acquiring knowledge of the handwriting and the cogency of the reasons for his

134. See 7 WIGMORE, op. cit. sipra note $2, \S 2015$, at 210 .

135. See note 11 supra.

136. See pp. 667-68 supra.

137. See note 115 supra.

138. MCCORMICK, EVIDENCE, $\$ 19$ (1954).

139. Hoag v. Wright, 174 N.Y. 36, 44, 66 N.E. 579, 581 (1903).

140. See Fekete v. Fekete, 323 III. 468, 154 N.E. 209 (1926); Keeney v. Arp De La Gardee, 212 Iowa 45, 235 N.W. 745 (1931).

141. Polley v. Cline's Ex'r, 263 Ky. 659, 93 S.W.2d 363 (1936); D'Angelo v. Nicolosi, 197 La. 797, 2 So. 2d 216 (1941).

142. Butman v. Christy, 197 Iowa 661, 198 N.W. 314 (1924) ; Fourth Nat'l Bank v. McArthur, 168 N.C. 48, 84 S.E. 39 (1915); cf. Keeney v. Arp De La Gardee, 212 Iowa 45, 235 N.W. 745 (1931).

143. Rosenthal v. Citizens State Bank, 266 P.2d 767 (Colo. 1954); In re McCarthy's Estate, 265 Wis. 548, 61 N.W.2d 819 (1954). 
opinions. . $^{144}$ In one jurisdiction, it has been held that it is never proper to instruct the jury that expert testimony is or is not reliable, or as to how the jury should appraise it. ${ }^{145}$ It has been held reversible error to disregard an expert's testimony. ${ }^{146}$ In Pennsylvania, the rule is that testimony of expert witnesses alone cannot support a finding of forgery. ${ }^{147}$ In others, findings of genuineness based on comparison with the aid of expert testimony have been sustained. ${ }^{148}$ Some courts hold that the positive testimony of unimpeached attesting witnesses is not outweighed by, and is more convincing than, the testimony of handwriting experts. ${ }^{149}$

Some of the attitudes antagonistic to expert testimony may be attributed to an historical distrust of comparison testimony in general. ${ }^{150}$ Others represent fears of possible bias on the part of the expert witness in that he may be too willing to give an opinion in accordance with the necessities of his employer's position. ${ }^{151}$ Regardless of its basis, these attitudes would seem to be justified in the case of the "expert" who is untrained in handwriting analysis since it is doubtful if such a witness is able to aid the trier of fact. However, in view of the progress which has been made in the technique of scientific handwriting analysis, disparaging instructions or reversals based on a deprecating view of the weight of expert testimony are out of place in the case of the handwriting analyst. To hold the opinions of persons who testify from their memory generally superior to the opinions of a handwriting analyst on the basis of a possible bias of experts is unrealistic and unfair. These persons may be equally subject to bias, bias may be exposed by cross-examination, and the relative superiority of expert opinion has been demonstrated. ${ }^{152}$ Since the handwriting analyst may be in error, the direct evidence of a purported eye-witness should be given appropriate weight. However, it is doubtful if the jury should be instructed to give greater weight to the purported witness' testimony than to the expert's opinion since many false claims have been based on definite and positive perjury. ${ }^{153}$ In any case, it is evident that the weight to be given the testimony of the expert witness on the basis of comparison by juxtaposition should be carefully reconsidered in many jurisdictions. There is little doubt that the opinion evidence of the witness trained in handwriting analysis is of great value and should be given greater weight than many courts have allowed it.

144. Kucaba v. Kucaba, 146 Neb. 116, 18 N.W.2d 645 (1945).

145. Hirshfeld v. Dana. 193 Cal. 142, 223 Pac. 451 (1924).

146. Nolan v. American Tel. \& Te1. Co., 326 I1l. App. 328, 61 N.E.2d 876 (1945). 147. Dworken v. McElwee, 355 Pa. 37, 48 A.2d 566 (1946).

148. In re Kreher's Estate, 107 Cal. App. 2d 831, 238 P.2d 150 (1951) ; Gaines v. Union Central Life Ins. Co., 191 Okla. 246, 129 P.2d 79 (1942) (semble).

149. Baird v. Shaffer, $101 \mathrm{Kan} .585,168$ Pac. 836 (1917); Wright v. Flynn, 69

N.J. Eq. 753, 61 Atl. 973 (Prerog. Ct. 1905); In re Henry's Estate, 276 Pa. 511, 120 At1. 454 (1923).

150. See text at note 16 supra.

151. See Polley v. Cline's Ex'r, 263 Ky. 659, 675, 93 S.W.2d 363, 371 (1936).

152. See text at notes 50 and 52 supra.

153. OsBoRn, op. cit. siepra note 1 , at 57-58. 